Brazilian Journal of Animal Science ISSN 1806-9290

www.rbz.org.br
*Corresponding author:

fibankuti@uem.br

Received: March 7, 2018

Accepted: October 18, 2018

How to cite: Defante, L.; Damasceno, J. C.;

Bánkuti, F. I. and Ramos, C. E. C. O. 2019.

Typology of dairy production systems that meet

Brazilian standards for milk quality. Revista

Brasileira de Zootecnia 48:e20180023.

https://doi.org/10.1590/rbz4820180023

Copyright: This is an open access article

distributed under the terms of the

Creative Commons Attribution License

(http://creativecommons.org/licenses/by/4.0/), which permits unrestricted use, distribution, and reproduction in any medium, provided the original work is properly cited.

\section{Typology of dairy production systems that meet Brazilian standards for milk quality}

\author{
Leslié Defante $^{1}$ (iD), Julio Cesar Damasceno ${ }^{2}$ iD, Ferenc Istvan Bánkuti ${ }^{2 *}$ iD, \\ Carlos Eduardo Crispim de Oliveira Ramos ${ }^{3}$ \\ ${ }^{1}$ Universidade Estadual de Maringá, Programa de Pós-Graduação em Zootecnia, Maringá, \\ PR, Brasil. \\ ${ }^{2}$ Universidade Estadual de Maringá, Departamento de Zootecnia, Maringá, PR, Brasil. \\ ${ }^{3}$ Universidade Federal do Recôncavo da Bahia, Centro de Ciências Agrárias, Ambientais e \\ Biológicas, Cruz das Almas, BA, Brasil.
}

\begin{abstract}
We aimed to compare the typology of dairy production systems (DPS) that meet Brazilian quality standards with that of non-compliant DPS. Semi-structured questionnaires were applied in 128 DPS located in Santa Izabel do Oeste, Paraná,

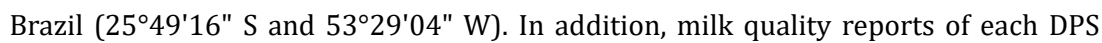
were analyzed. Dairy production systems were segregated into two groups: G1 - DPS that were in accordance with Brazilian regulations on milk quality, and G2 - DPS that did not comply with Brazilian regulations. Exploratory factor analysis was performed on structural, production, and technical variables. Two factors were defined: F1 production scale and bargaining power, and F2 - autonomy and production control. Groups 1 and 2 were evaluated according to their structural, production, and technical characteristics as well as their F1 and F2 values. A small fraction (6.25\%) of DPS met the minimum quality standards for milk. Dairy production systems that comply with quality regulations have larger production scale, higher productivity, and greater autonomy and control of milk production. Consequently, they have better bargaining power with the industry for the marketing of milk.
\end{abstract}

Keywords: agricultural systems, dairy cattle, milk composition, somatic cell count

\title{
Introduction
}

The state of Paraná contributes with 14\% of the national milk production and is the second largest milk producer in Brazil (IBGE, 2016). Milk production in Paraná generates jobs and income for more than 114,000 families (Telles et al., 2008). Despite the critical role of dairy production in Paraná and in the country, milk produced in Brazil is considered of low quality (Souza et al., 2014; Sambuichi et al., 2012) and often fails to meet the minimum quality criteria of the Brazilian legislation (Silva et al., 2011; Fialho et al., 2012; Ribeiro Júnior et al., 2013; Vallin et al., 2009; Yamazi et al., 2010). Normative Instructions (NI) nos. 51 and 62 establish quality criteria regarding the physical, chemical, and microbiological characteristics of milk, including the maximum limits of somatic cell count (SCC) and standard plate count (SPC) (Brasil, 2002, 2011). Non-conformity with quality regulations prompts dairy producers to operate in the informal market or even abandon the activity (Bánkuti et al., 2009; Souza and Alves, 2010; Souza and Buainain, 2013). Milk quality is associated with technical and production characteristics of DPS, including production scale, system management and control practices, milk cooling processes, and hygiene of the milking process. 
Therefore, improvement of milk quality demands advances in the entire production process. For the industry, an improved production process can result in higher yields and generate a product with enhanced sensory quality and longer shelf life. For rural producers, higher milk quality can lead to higher sales prices (Dürr, 2004; Fialho et al., 2012; Takahashi et al., 2012), more income, stimulus to production, and greater access to the external market (Oliveira and Silva, 2012; Taffarel et al., 2015). We aimed to analyze and compare the typology of DPS that meet Brazilian quality standards with that of non-compliant DPS.

\section{Material and Methods}

Semi-structured questionnaires were applied in 128 DPS located in Santa Izabel do Oeste, Paraná, Brazil (25 49' $16^{\prime \prime} \mathrm{S}$ and $53^{\circ} 29^{\prime} 04^{\prime \prime} \mathrm{W}$ ). The municipality was chosen because of its representativeness of milk production in Paraná and because of its easy access to the research team. In 2016, 31.2 million liters of milk was produced in Santa Izabel do Oeste, which generated R\$38.6 million (IBGE, 2016). Dairy production systems were randomly selected from a list provided by DPS cooperatives and technical assistance agencies. Twenty variables were analyzed: 18 accounted for structural, production, and technical characteristics and two represented social characteristics (Table 1).

Table 1 - Description of categorical and numerical variables used to characterize dairy production systems

Type

Variable
1. Total farm area (ha)
2. Production area (ha)
3. Individual animal records
4. Management of milk productivity per cow
5. Dairy cows (n)
6. Lactating cows (n)
7. Milk productivity (L day $\left.{ }^{-1}\right)$
8. Milk productivity per cow (L day $\left.{ }^{-1} \mathrm{cow}^{-1}\right)$

9. Pre-and post-milking teat disinfection

1 - Not performed; 2 - Pre-milking disinfection only;

3 - Post-milking disinfection only; 4 - Pre- and postmilking teat disinfection is performed

10. Frequency of milk quality testing

1 - Milk quality is not tested; 2 - Milk quality is tested a few times a year; 3 - Milk quality is tested monthly

1 - No; 2 - Yes, we have signed an agreement to improve milk quality and productivity

Absolute value

Absolute value

1 - Not used; 2 - Only for lactating cows; 3 - All animals have individual records

1 - Not performed; 2 - Monthly control; 3 - Daily

Absolute value

Absolute value

Absolute value

Absolute value

Numerical

Numerical

Categorical

Categorical

Numerical

Numerical

Numerical

Numerical

Categorical

Categorical

11. Milk supply agreements

12. Management of revenues and expenses

13. Financial incentives to increase milk productivity and quality

14. Other incentives to improve milk quality

15. Facilities for worker welfare

16. Facilities for animal welfare

17. Access of animals to shade

18. Milking room and milk cooler

19. Years in the dairy business

1 - Not performed; 2 - Revenue management only;

3 - Expense management only; 4 - We manage both revenues and expenses

1 - No; 2 - Yes

1 - No; 2 - Yes

1 - No; 2 - Inadequate facilities; 3- Adequate facilities

$$
1 \text { - No; } 2 \text { - Yes }
$$

1 - No; 2 - Some plots offer shade; 3 - All plots offer shade

1 - No; 2 - Yes, but cold water is used for cooling milk; 3 - Yes, a milk cooler is used

Absolute value

Absolute value

20 . Age of the business proprietor

Numerical

${ }^{1} 1$ to 18 - Structural, technical, and production variables of dairy production systems; 19 and 20 - social variables of rural producers. 
Variables were of two types, numerical or categorical. A classification score was adopted for categorical variables (Hair et al., 2009). The lowest score corresponded to the least adequate technical, production, or structural situation, whereas the highest score was attributed to the most adequate technical, production, or structural situation (Table 1).

Descriptive statistics (mean and standard deviation) were calculated for each variable to characterize DPS.

We assessed milk quality by analyzing SCC and SPC in milk over 36 consecutive months. Milk quality variables were provided by industries that bought milk from DPS. Quality analyses were conducted by an accredited institution.

The maximum limits for SCC and SPC according to Brazilian NI no. 62 (Brasil, 2011) are 500,000 somatic cells $/ \mathrm{mL}$ and 300,000 colony forming units $(\mathrm{cfu}) / \mathrm{mL}$, respectively. Dairy production systems were segregated into two groups. The first group (G1) comprised the eight DPS that were in accordance with NI no. 62 and the second group (G) comprised the 120 DPS that did not meet NI no. 62 SCC and SPC standards (Table 2).

Groups 1 and 2 were analyzed according to the following production and productivity variables: total farm area (ha), production area (ha), dairy cows (n), lactating cows (n), milk productivity (L day ${ }^{-1}$ ), and milk productivity per cow $\left(\mathrm{L} \mathrm{day}^{-1} \mathrm{cow}^{-1}\right)$. We performed Kolmogorov-Smirnov and Shapiro-Wilk tests for normality and Levene's test for homogeneity of variance (Field, 2009). In case of non-normality, residuals were analyzed using generalized linear models with gamma distribution and Wald chi-square test. With this procedure, it was possible to identify the typology of compliant and non-compliant DPS according to the quality standards of Brazilian regulations.

Exploratory factor analysis (EFA) was applied to the structural, production, and technical variables. Principal component analysis was used as the extraction method and was followed by varimax rotation with Kaiser-Meyer-Olkin (KMO) measure of sampling adequacy and Bartlett's test of sphericity (Barroso and Artes, 2003; Brito et al., 2015; Smith et al., 2002). We retained factors defined by one or more explanatory variables that had a significant ( $>0.5$ ) factor loading (Fávero et al., 2009; Yabe et al., 2015). Factor scores were saved as regression variables; thus, each DPS received a contribution score for each factor. In the regression method, factor loadings are adjusted from the initial correlation between variables, eliminating possible differences between units of measure and stabilizing variances. This procedure allows factor scores to be analyzed in several manners, including in mean tests (Field, 2009).

Groups 1 and 2 were analyzed according to factor loadings (Brito et al., 2015; Zimpel et al., 2017) to determine which factor most distinguishes compliant DPS from non-compliant DPS.

\section{Results}

The mean total farm area of the 128 DPS was $11.21 \pm 10.18$ ha, and the mean production area was $7.83 \pm 6.21$ ha. The mean numbers of cows and lactating cows were $21.47 \pm 12.36$ and $11.88 \pm 6.35$, respectively. Mean milk productivity was $147.70 \pm 154.09 \mathrm{~L} \mathrm{day}^{-1}$. The mean age of farmers (i.e., decision makers) was relatively high $(49.18 \pm 11.51$ years old), and most farmers had ample experience with dairy production $(25 \pm 13.29$ years $)$.

Compliant and non-compliant DPS did not differ significantly ( $>0.10$ ) (Table 3) in terms of total farm area and production area. However, compliant DPS had more dairy cows $(\mathrm{P}<0.06)$, more lactating

Table 2 - Milk quality in dairy production systems classified as compliant or non-compliant with Brazilian standards

\begin{tabular}{lcccc}
\hline Group & $\mathrm{N}$ & $\%$ & SCC & SPC \\
\hline G1 (compliant) & 8 & 6.25 & 367.66 & 176.79 \\
G2 (non-compliant) & 120 & 93.75 & 652.57 & $2,515.08$ \\
\hline
\end{tabular}

SCC - somatic cell count (somatic cells/mL); SPC - standard plate count (cfu/mL).

Note: Brazilian legislation on milk quality establishes an SCC limit of 500,000 somatic cells/mL and an SPC limit of 300,000 cfu/mL (Brasil, 2011).

R. Bras. Zootec., 48:e20180023, 2019 
cows $(\mathrm{P}<0.05)$, higher milk productivity $(\mathrm{P}<0.07)$, and higher milk productivity per cow $(\mathrm{P}<0.07)$ than non-compliant DPS (Table 3).

The KMO test (0.845) and Bartlett's test of sphericity (0.000) applied to the 18 variables revealed good factorability of data (Fávero et al., 2009; Hair et al., 2009). The first two factors in EFA (factor 1, F1; factor 2, F2) explained 52\% of the total variance, satisfying the requirements for factor extraction (Fávero et al., 2009; Hair et al., 2009) (Table 4).

Factor 1 explained the most variance (36.97\%) among DPS (Table 4). It was composed of the following variables: dairy cows (n), lactating cows (n), milk productivity $\left(\mathrm{L} \mathrm{day}^{-1}\right)$, milk productivity per cow ( $\mathrm{L} \mathrm{day}^{-1} \mathrm{cow}^{-1}$ ), frequency of milk quality testing, milk supply agreements, financial incentives to increase milk productivity and quality, and other incentives to improve milk quality (Table 5). The variables that compose F1 are indicative of the scale of production and bargaining power of rural producers in transactions with the industry. Given these characteristics, F1 was labeled as "production scale and bargaining power."

The fact that F1 explained most of the variance among DPS suggests that scale of production and bargaining power are the main characteristics that distinguish DPS of G1 from those of G2.

Factor 2 was composed of the variables total farm area (ha), production area (ha), individual animal records, pre- and post-milking teat disinfection, management of revenues and expenses, facilities for worker welfare, facilities for animal welfare, access of animals to shade, milking room, and milk cooler (Table 5). These variables can provide information on the autonomy of farms in feed production, production control, working conditions, and system management as well as on variables that are strongly linked to the quality of milk, such as milking hygiene practices, and conditions of milk storage in the rural property (Almeida et al., 2015; Santana et al., 2004; Vallin et al., 2009). Thus, F2 was considered to represent the "autonomy and production control" of DPS (Table 5).

Table 3 - Typology of groups

\begin{tabular}{|c|c|c|c|}
\hline Variable & Group ${ }^{1}$ & Mean & SD \\
\hline \multirow{2}{*}{ Total farm area (ha) } & G1 & 10.062 & 5.882 \\
\hline & G2 & 11.286 & 10.415 \\
\hline \multirow{2}{*}{ Production area (ha) } & G1 & 7.812 & 4.628 \\
\hline & $\mathrm{G} 2$ & 7.831 & 6.317 \\
\hline \multirow{2}{*}{ Dairy cows $(n)^{2}$} & G1 & $29.000 \mathrm{a}$ & 18.024 \\
\hline & G2 & $20.980 \mathrm{~b}$ & 11.827 \\
\hline \multirow{2}{*}{ Lactating cows $(n)^{3}$} & G1 & $17.500 \mathrm{a}$ & 11.551 \\
\hline & G2 & $11.510 \mathrm{~b}$ & 5.748 \\
\hline \multirow{2}{*}{ Milk productivity $\left(\mathrm{L} \mathrm{day}^{-1}\right)^{4}$} & G1 & $298.000 \mathrm{a}$ & 311.216 \\
\hline & G2 & $137.680 \mathrm{~b}$ & 134.255 \\
\hline \multirow{2}{*}{ Milk productivity per cow $\left(\mathrm{L} \mathrm{day}^{-1} \mathrm{cow}^{-1}\right)^{4}$} & G1 & $13.750 \mathrm{a}$ & 6.719 \\
\hline & $\mathrm{G} 2$ & $10.620 \mathrm{~b}$ & 4.191 \\
\hline
\end{tabular}

SD - standard deviation.

${ }_{1}^{1} \mathrm{G} 1$ : compliant dairy production systems; G2: non-compliant dairy production systems.

${ }^{2}$ Means followed by different letters differ significantly at $\mathrm{P}<0.06$.

${ }^{3}$ Means followed by different letters differ significantly at $\mathrm{P}<0.05$.

${ }^{4}$ Means within a variable followed by different letters differ significantly at $\mathrm{P}<0.07$.

Table 4 - Total variance explained by factors 1 and 2

\begin{tabular}{lccc}
\hline Factor $^{1}$ & Total & \% of variance & Cumulative \% \\
\hline F1 & 8.134 & 36.971 & 36.971 \\
F2 & 3.319 & 15.085 & 52.056 \\
\hline
\end{tabular}

${ }^{1}$ F1: production scale and bargaining power; F2: autonomy and production control. 
Table 5 - Factor loadings

\begin{tabular}{lcc}
\hline & \multicolumn{2}{c}{ Factor $^{1}$} \\
\cline { 2 - 3 } Variable & $\mathrm{F} 1$ & $\mathrm{~F} 2$ \\
\hline 1. Total farm area (ha) & 0.305 & $0.617^{*}$ \\
2. Production area (ha) & 0.433 & $0.598^{*}$ \\
3. Individual animal records & 0.355 & $0.574^{*}$ \\
4. Management of milk productivity per cow & $0.579^{*}$ & 0.346 \\
5. Dairy cows (n) & $0.667^{*}$ & 0.388 \\
6. Lactating cows (n) & $0.730^{*}$ & 0.498 \\
7. Milk productivity (L day ${ }^{-1}$ ) & $0.910^{*}$ & 0.308 \\
8. Milk productivity per cow (L day ${ }^{-1}$ cow ${ }^{-1}$ ) & $0.779^{*}$ & 0.348 \\
9. Pre- and post-milking teat disinfection & 0.268 & $0.599^{*}$ \\
10. Frequency of milk quality testing & $0.785^{*}$ & 0.038 \\
11. Milk supply agreements & $0.589^{*}$ & 0.141 \\
12. Management of revenues and expenses & 0.219 & $0.640^{*}$ \\
13. Financial incentives to increase milk productivity and quality & $0.851^{*}$ & 0.152 \\
14. Other incentives to improve milk quality & $0.748^{*}$ & 0.042 \\
15. Facilities for worker welfare & 0.326 & $0.655^{*}$ \\
16. Facilities for animal welfare & 0.009 & $0.613^{*}$ \\
17. Access of animals to shade & -0.015 & $0.577^{*}$ \\
18. Milking room and milk cooler & 0.101 & $0.649^{*}$ \\
\hline 1. producton scal and barganing power; & & \\
\end{tabular}

${ }^{1} \mathrm{~F} 1$ : production scale and bargaining power; F2: autonomy and production control.

${ }^{*}$ Factor loadings $>0.5$.

Table 6 - Mean factor loadings of dairy production systems classified as compliant or non-compliant with Brazilian legislation on milk quality

\begin{tabular}{lcc}
\hline \multirow{2}{*}{ Group } & \multicolumn{2}{c}{ Mean factor loading $^{1}$} \\
\cline { 2 - 3 } & F1 & F2 \\
\hline G1 (Compliant) & 0.8745 & 0.1652 \\
G2 (Non-compliant) & -0.0583 & -0.0110 \\
\hline
\end{tabular}

${ }^{1}$ F1: Production scale and bargaining power; F2: autonomy and production control.

Group 1 (compliant) DPS had higher mean factor loadings for production scale and bargaining power (F1) and autonomy and production control (F2) than G2 (non-compliant) DPS (Table 6). This result indicates that DPS that meet the quality standards defined by Brazilian legislation have, in general, larger scale of production, greater bargaining power, greater autonomy, and better control of production than non-compliant DPS.

\section{Discussion}

Most of the analyzed DPS did not comply with all legal requirements for milk quality defined by NI no. 62 (Brasil, 2011). Results of SPC exceeding the regulatory limit indicate either ineffective cleaning and disinfection procedures for milking equipment, cooling systems, and cow teats or the occurrence of mastitis (Elmoslemany et al., 2009; Marion Filho and Oliveira, 2011; Taffarel et al., 2013). Somatic cell count is indicative of udder health, milk quality, and cow welfare. High SCC values also indicate the presence of mastitis (Rysanek et al., 2007; Cicconi-Hogan et al., 2013).

High SCC milk is a cause for concern for industries, as it can affect fermentation and coagulation processes, decreasing the yield of dairy products, such as cheese and butter (Coelho et al., 2014). 
Furthermore, high SCC milk can result in products with reduced shelf life (Barbano et al., 2006). Values of SCC and SPC can be influenced by the season of the year, environmental variables, lactation, and volume of milk produced per cow (Takahashi et al., 2012).

We found that compliant DPS had higher milk productivity, greater bargaining power with the dairy industry, greater autonomy, and greater control of milk production than non-compliant DPS. The vast majority (93.75\%) of the analyzed DPS did not comply with quality standards and had fewer dairy cows, fewer lactating cows, lower productivity, lower productivity per cow, and fewer management and control procedures than compliant DPS.

Proper milking hygiene, milk cooling methods, and mastitis control were more frequent in larger DPS, as these practices require investment in employee training, equipment, and production techniques (Ingham et al., 2011). Milk losses associated with quality problems have a lower economic impact on large-scale DPS compared with small-scale DPS (Ingham et al., 2011). Nevertheless, large-scale DPS have better control of milk quality and sanitary standards than small-scale DPS (Dong et al., 2012).

Compliant DPS had adequate facilities for worker and animal welfare and used more specialized breeds for milk production. Compared with non-compliant DPS, compliant DPS performed more efficiently and had better management and production practices, controlling revenues, expenses, and milk productivity per cow.

Compliant DPS also had positive relationships with the industry. Technical assistance and subsidies were provided more frequently to compliant DPS than to non-compliant DPS, as the former met quality and volume criteria more often. Financial incentives represent an important strategy for improving the quality of milk (Ribeiro Júnior et al., 2014).

The volume of milk sold by the rural producer to the industry affects the price of milk; producers are paid better prices for larger volumes of milk (Magalhães, 2007; Bánkuti et al., 2008). For the industry, the higher price is compensated by a reduced freight cost. In addition, knowledge on milk composition increases the bargaining power of the farmer in transactions with the industry and reduces asymmetries of information and possible opportunistic actions by the buyer (Magalhães, 2007; Fernandez-Stark et al., 2012; Brito et al., 2015).

Success in the dairy activity is associated with the ability to control animal performance parameters and manage the system as a whole (IPARDES, 2009). Simple management and control practices, such as monitoring production and economic indicators, are able to help rural producers in making safe decisions (Atzori et al., 2013; Zimpel et al., 2017).

Small-scale DPS have more difficulty in meeting milk quality standards. Low milk productivity and poor hygiene conditions are more common in small-scale DPS (Pedrico et al., 2009). Analysis of structural, technical, and production characteristics of DPS compliant with NI no. 62 revealed that these farms had higher productivity and produced milk of higher quality. These results indicate that, compared with non-compliant DPS, compliant DPS have higher chances of remaining competitive in the medium and long term.

\section{Conclusions}

A small fraction of dairy production systems comply with milk quality requirements of the Brazilian legislation. Dairy production systems that meet quality standards have larger scale of production, higher productivity, greater autonomy, and better control of milk production. Consequently, compliant DPS have greater bargaining power with the industry for the marketing of milk.

\section{Acknowledgments}

The authors thank CAPES - Coordenação de Aperfeiçoamento de Pessoal de Nível Superior, for the financial support. 


\section{References}

Almeida, T. J. O.; Araújo, V. C.; Feitosa, P. J. S. and Silva, A. F. A. 2015. Perfil sociocultural de produtores de leite bovino do município de São Bento do Una (PE) e suas implicações sobre o manejo da ordenha. Revista Brasileira de Higiene e Sanidade Animal 9:122-135.

Atzori, A. S.; Tedeschi, L. O. and Cannas, A. 2013. A multivariate and stochastic approach to identify key variables to rank dairy farms on profitability. Journal of Dairy Science 96:3378-3387. https://doi.org/10.3168/jds.2012-6256

Bánkuti, F. I.; Souza Filho, H. M. and Bánkuti, S. M. S. 2008. Mensuração e análise de custos de transação arcados por produtores de leite nos mercados formal e informal da região de São Carlos, SP. Organizações Rurais \& Agroindustriais 10:343-358

Bánkuti, F. I.; Bánkuti, S. M. S. and Souza Filho, H. M. 2009. Entraves para inserção de produtores de leite no mercado formal da Região de São Carlos, Estado de São Paulo. Informações Econômicas 39:11.

Barbano, D. M.; Ma, Y. and Santos, M. V. 2006. Influence of raw milk quality on fluid milk shelf life. Journal of Dairy Science 89:E15-E19. https://doi.org/10.3168/jds.S0022-0302(06)72360-8

Barroso, L. P. and Artes, R. 2003. Análise multivariada. Universidade Federal de Lavras, Lavras.

Brasil. Ministério da Agricultura, Pecuária e Abastecimento. 2002. Instrução Normativa № 51, de 18 de setembro de 2002. Diário Oficial da União, Brasília, DF, 20 set. 2002.

Brasil. Ministério da Agricultura, Pecuária e Abastecimento. 2011. Instrução Normativa n. 62, de 29 de dezembro de 2011. Diário Oficial da União, Brasília, DF, 30 dez. 2011.

Brito, M. M.; Bánkuti, F. I.; Bánkuti, S. M. S.; Ferreira, M. C. M.; Damasceno, J. C.; Santos, G. T. and Zambom, M. A. 2015. Horizontal arrangements: strategy for reducing the asymmetry information for dairy farmers in Paraná, Brazil. Ciência Rural 45:2069-2075. https://doi.org/10.1590/0103-8478cr20141724

Cicconi-Hogan, K. M.; Gamroth, M.; Richert, R.; Ruegg, P. L.; Stiglbauer, K. E. and Schukken, Y. H. 2013. Associations of risk factors with somatic cell count in bulk tank milk on organic and conventional dairy farms in the United States. Journal of Dairy Science 96:3689-3702. https://doi.org/10.3168/jds.2012-6271

Coelho, K. 0.; Mesquita, A. J.; Machado, P. F.; Lage, M. E.; Meyer, P. M. and Reis, A. P. 2014. Efeito da contagem de células somáticas sobre o rendimento e a composição físico-química do queijo muçarela. Arquivo Brasileiro de Medicina Veterinária e Zootecnia 66:1260-1268. https://doi.org/10.1590/1678-7616

Dong, F.; Hennessy, D. A. and Jensen, H. H. 2012. Factors determining milk quality and implications for production structure under somatic cell count standard modification. Journal of Dairy Science 95:6421-6435. https://doi.org/10.3168/ jds.2012-5522

Dürr, J. W. 2004. Programa Nacional de Melhoria da Qualidade do Leite: uma oportunidade única. p.38-55. In: 0 compromisso com a qualidade do leite. Universidade de Passo Fundo, Passo Fundo.

Elmoslemany, A. M.; Keefe, G. P.; Dohoo, I. R. and Jayarao, B. M. 2009. Risk factors for bacteriological quality of bulk tank milk in Prince Edward Island dairy herds. Part 1: overall risk factors. Journal of Dairy Science 92:2634-2643. https://doi.org/10.3168/jds.2008-1812

Fávero, L. P.; Belfiore, P. P.; Silva, F. L. and Chan, B. L. 2009. Análise de dados: Modelagem multivariada para tomada de decisões. Análise de dados: modelagem multivariada para tomada de decisões. 3.ed. Elsevier, Rio de Janeiro.

Fernandez-Stark, K.; Bamber, P. and Gereffi, G. 2012. Inclusion of small- and medium-sized producers in value chains. Center on Globalization, Governance \& Competitiveness. 38p.

Fialho, T. L.; Eugênio, M. H. A.; Silvério, A. S. D.; Melo, C. M. S.; Abreu, L. R. and Pinto, S. M. 2012. Evolução da qualidade do leite de cooperativas da região do Alto Paranaíba perante a instrução normativa 51. Revista do Instituto de Laticínios Cândido Tostes 67:53-57.

Field, A. 2009. Descobrindo a estatística usando o SPSS. 2.ed. Artmed, Porto Alegre.

Hair, J. F. J.; Black, W. C.; Babin, B. J. and Anderson, R. E. 2009. Multivariate data analysis. 7th ed. Prentice Hall, Saddle River. IBGE - Instituto Brasileiro de Geografia e Estatística. 2016. Pesquisa trimestral do leite.

Ingham, S. C.; Hu, Y. and Ané, C. 2011. Comparison of bulk-tank standard plate count and somatic cell count for Wisconsin dairy farms in three size categories. Journal of Dairy Science 94:4237-4241. https://doi.org/10.3168/jds.2011-4310

IPARDES - Instituto Paranaense de Desenvolvimento Econômico e Social. 2009. Caracterização socioeconômica da atividade leiteira do Paraná. Instituto Paranaense de Desenvolvimento Econômico e Social e Instituo Paranaense de Assistência Técnica e Extensão Rural. Curitiba, PR.

Magalhães, R. S. 2007. Habilidades sociais no mercado de leite. Revista de Administração de Empresas 47:15-25. https://doi.org/10.1590/S0034-75902007000200003

R. Bras. Zootec., 48:e20180023, 2019 
Marion Filho, P. J. and Oliveira, L. F. V. 2011. A especialização e a concentração da produção de leite nas microrregiões do Rio Grande do Sul (1990-2007). Ensaios FEE 31:635-647.

Oliveira, L. F. T. and Silva, S. P. 2012. Mudanças institucionais e produção familiar na cadeia produtiva do leite no Oeste Catarinense. Revista de Economia e Sociologia Rural 50:705-720. https://doi.org/10.1590/S0103-20032012000400007

Pedrico, A.; Castro, J. G. D.; Silva, J. E. C. and Machado, L. A. R. 2009. Aspectos higiênico-sanitários na obtenção do leite no assentamento Alegre, município de Araguaína, TO. Ciência Animal Brasileira 10:610-617.

Ribeiro Júnior, J. C.; Beloti, V.; Silva, L. C. C. and Tamanini, R. 2013. Avaliação da qualidade microbiológica e físico-química do leite cru refrigerado produzido na região de Ivaiporã, Paraná. Revista do Instituto de Laticínios Cândido Tostes 68:5-11.

Ribeiro Júnior, J. C.; Shecaira, C. L.; Silva, F. F.; Parren, G. E. and Beloti. V. 2014. Influência de boas práticas de higiene de ordenha na qualidade microbiológica do leite cru refrigerado. Revista do Instituto de Laticínios Cândido Tostes 69:395-404. https://doi.org/10.14295/2238-6416.v69i6.343

Rysanek, D.; Babak, V. and Zouharova, M. 2007. Bulk tank milk somatic cell count and sources of raw milk contamination with mastitis pathogens. Veterinarni Medicina 52:223-230. https://doi.org/10.17221/1878-VETMED

Sambuichi, R. H. R.; Oliveira, M. A. C.; Silva, A. P. M. and Luedemann, G. 2012. A sustentabilidade ambiental da agropecuária brasileira: impactos, políticas públicas e desafios. Instituto de Pesquisa Economica Aplicada, Rio de Janeiro. (Texto para Discussão 1782).

Santana, E. H. W.; Beloti, V.; Müller, E. E.; Ferreira, M. D. A.; Moraes, L. B.; Pereira, M. S. and Gusmão, V. V. 2004. Milk contamination in different points of the dairy process. ii) mesophilic, psychrotrophic and proteolytic microorganisms. Semina: Ciências Agrárias 25:349-358.

Silva, L. C. C.; Beloti, V.; Tamanini, R.; d'Ovidio, L.; Mattos, M. R.; Arruda, A. M. C. T. and Pires, E. M. F. 2011. Tracking sources of microbiologic contamination of raw milk during milking process in dairy farms from Agreste of Pernambuco. Semina: Ciências Agrárias 32:267-276.

Smith, R. R.; Moreira, L. V. and Latrille, L. L. 2002. Caracterización de sistemas productivos lecheros em la X Región de Chile mediante análisis multivariable. Agricultura Técnica 62:375-395. https://doi.org/10.4067/S0365-28072002000300004

Souza, A. P.; Honorato, L. A.; Gómez, C. U.; Cardoso, C. S. and Hötzel, M. J. 2014. Construção e uso de indicadores para avaliação do manejo da ordenha: uma proposta metodológica participativa. Ciência Rural 44:911-917. https://doi.org/10.1590/S0103-84782014000500024

Souza, R. P. and Buainain, A. M. 2013. A competitividade da produção de leite da agricultura familiar: os limites da exclusão. Estudos Sociedade e Agricultura 21:308-331.

Souza, J. B. L. and Alves, A. F. 2010. Especialização produtiva e retornos associados para os produtores de leite. Economia e Tecnologia 23:151-160. https://doi.org/10.5380/ret.v6i4.26923

Taffarel, L. E.; Costa, P. B.; Oliveira, N. T. E.; Braga, G. C. and Zonin, W. J. 2013. Contagem bacteriana total do leite em diferentes sistemas de ordenha e de resfriamento. Arquivo do Instituto Biológico de São Paulo 80:7-11.

Taffarel, L. E.; Costa, P. B.; Tsutsumi, C. Y.; Klosowski, E. S.; Portugal, E. F. and Lins, A. C. 2015. Variação da composição e qualidade do leite em função do volume de produção, período do ano e sistemas de ordenha e de resfriamento. Semina: Ciências Agrárias 36:2287-2300

Takahashi, F. H.; Cassoli, L. D.; Zampar, A. and Machado, P. F. 2012. Variação e monitoramento da qualidade do leite através do controle estatístico de processos. Ciência Animal Brasileira 13:99-107.

Telles, T. S.; Tanaka, J. M. U. and Pellini, T. 2008. Agricultura familiar: pecuária leiteira como locus das políticas públicas paranaenses. Semina: Ciências Agrárias 29:579-590.

Vallin, V. M.; Beloti, V.; Battaglini, A. P. P.; Tamanini, R.; Fagnani, R.; Angela, H. L. and Silva, L. C. C. 2009. Melhoria da qualidade do leite a partir da implantação de boas práticas de higiene na ordenha em 19 municípios da região central do Paraná. Semina: Ciências Agrárias 30:181-188.

Yabe, M. T.; Bánkuti, F. I.; Damasceno, J. C. and Brito, M. M. 2015. Characteristics of milk production systems and feed strategies for dairy cows in the North and Northwest of Paraná State. Semina: Ciências Agrárias 36:4469-4480. https://doi.org/10.5433/1679-0359.2015v36n6Supl2p4469

Yamazi, A. K.; Moraes, P. M.; Viçosa, G. N.; Ortolani, M. B. T. and Nero, L. A. 2010. Práticas de produção aplicadas no controle de contaminação microbiana na produção de leite cru. Bioscience Journal 26:610-618.

Zimpel, R.; Bánkuti, F. I.; Zambom, M. A.; Kuwahara, K. C. and Bánkuti, S. M. S. 2017. Characteristics of the dairy farmers who perform financial management in Paraná State, Brazil. Revista Brasileira de Zootecnia 46:421-428. https://doi.org/10.1590/s1806-92902017000500008 